Homegrown Hate 



\section{Homegrown Hate}

Why White Nationalists and Militant

Islamists Are Waging War against

the United States

\section{Sara Kamali}

口 
University of California Press

Oakland, California

(C) 202 I by Sara Kamali

Library of Congress Cataloging-in-Publication Data

Names: Kamali, Sara, author.

Title: Homegrown hate : why white nationalists and militant Islamists are waging war against the United States / Sara Kamali.

Description: Oakland, California : University of California Press, [202I] I Includes bibliographical references and index.

Identifiers: LCCN 2020029262 (print) | LCCN 2020029263 (ebook) I ISBN 9780520360020 (cloth) I ISBN 9780520976II 5 (ebook)

Subjects: LCSH: Domestic terrorism-United StatesPrevention. I White nationalism-United States. I Islamic fundamentalism-United States. I Religious militants-United States.

Classification: LCC HV6432.K344 202I (print) I LCC HV6432 (ebook) I DDC 363.3250973-dc23

LC record available at https://lccn.loc.gov/2020029262

LC ebook record available at https://lccn.loc .gov/2020029263

Manufactured in the United States of America

$\begin{array}{llllllllll}30 & 29 & 28 & 27 & 26 & 25 & 24 & 23 & 22 & 21\end{array}$

$\begin{array}{llllllllll}\text { IO } & 9 & 8 & 7 & 6 & 5 & 4 & 3 & 2 & \text { I }\end{array}$ 
For my mother

and

for the warriors of peace, of all creeds and colors,

who strive against inequity, oppression, and

impunity 
America is a unique sociological fabric, and it bespeaks poverty of imagination not to be thrilled at the incalculable potentialities of so novel a union of men. To seek no other goal than the weary old nationalism,--belligerent, exclusive, inbreeding, the poison of which we are witnessing now in Europe,-is to make patriotism a hollow sham, and to declare that, in spite of our boastings, America must ever be a follower and not a leader of nations.

-Randolph S. Bourne, Atlantic Monthly, July I9I6 